\begin{abstract}
This paper brings together the literature on determination of home bias in equity holdings and the portfolio balance model of exchange rates to consider whether the dollar might be affected by a change in transactions costs that alters international portfolio allocations. Our empirical findings lend support to the view that transactions costs have a significant influence on US portfolio holdings, even after accounting for float market share. In addition, new survey evidence on the equity holdings of European firms indicates home bias for European investors, and points to a reduction in the magnitude of this home bias since 1997.
\end{abstract}

Keywords: portfolio choice, equity flows, exchange rates

JEL classification: F21, F31, G11, G15

This paper was produced as part of the Centre's International Financial Stability Programme

\title{
Acknowledgements
}

An abridged version of this paper entitled 'Home Bias, Transactions Costs, and Prospects for the Euro' is forthcoming in Asset Price Bubbles: The Implications for Monetary, Regulatory, and International Policies, W.C. Hunter, ed., MIT Press. We thank Frank Warnock for comments on an earlier draft and Josh Catlin for research assistance.

Catherine Mann is a member of the Institute for International Economics, 1750

Massachusetts Avenue NW, Washington, DC 20036. Contact: clmann@iie.com

Ellen Meade is a member of the Centre for Economic Performance, London School of Economics and Political Science, Houghton Street, London WC2A 2AE.

Contact: e.e.meade@1se.ac.uk

Published by

Centre for Economic Performance

London School of Economics and Political Science

Houghton Street

London WC2A $2 \mathrm{AE}$

(C) Catherine L. Mann and Ellen E. Meade, submitted June 2002

ISBN 0753015552

Individual copy price: $£ 5$ 


\section{Home Bias, Transactions Costs, and Prospects for the Euro: A More Detailed Analysis}

\section{Catherine L. Mann and Ellen E. Meade}

\section{June 2002}

1. Overview 1

2. Portfolio Allocations and Transactions Costs 2

3. Portfolio Allocations and Exchange Rates 5

4. The US Investor $\quad 6$

5. The European Investor $\quad 9$

6. Implications for the Euro/Dollar Exchange Rate 13

7. Remarks on European Financial Market Consolidation and Future Work 14

$\begin{array}{ll}\text { Tables } & 16\end{array}$

$\begin{array}{ll}\text { Charts } & 20\end{array}$

Appendix: Data Sources $\quad 24$

$\begin{array}{ll}\text { References } & 25\end{array}$ 


\section{Overview}

This paper brings together two strands of the international finance literature: home bias and transactions costs, and international portfolio flows and exchange ate movements. Each strand of the literature has substantial depth, and the questions that researchers investigate within each strand are not answered unequivocally. Consequently, our goal is to synthesize only some of the research and consider one general and one specific question: would the US dollar depreciate if the transactions costs associated with trading equities in non-US markets were to fall to the level of transactions costs on US exchanges? More specifically, given the interest in Europe on the development of a single market - including a pan-European financial market - is the current value of the euro low relative to the dollar because of higher transactions costs in European equity markets?

Answering these questions takes several steps. First, we need to understand better the nature of transactions costs and their implications for investment strategies in international assets. Second, we need to consider the evidence that a change in international portfolio flows can affect the exchange value of a currency. Finally, we can consider the sensitivity of the links between transactions costs, international portfolio allocations and net capital flows, and the exchange rate. This paper investigates the first of these steps.

\section{Narrowing the exercise}

We focus in this paper on equity markets and the global portfolio behaviour of US and European investors, rather than the universe of assets (currency, official securities, corporate bonds) or investors. Equity markets have grown very rapidly in recent years as countries have deregulated financial markets, and the US and European equity markets account for about $3 / 4$ of world market capitalization.

To examine the behaviour of the US investor, we use the 1997 benchmark survey of US holdings of foreign equities. US invested wealth is large, but the share of US equity wealth invested abroad is quite small (about 12 percent). If transactions costs are an important determinant of this allocation, then the effect of a change in transactions costs on US portfolio allocations and cross-border equity flows could be large, with implications for the dollar. 
To investigate the behaviour of the European investor, we examine the allocations over time of equity portfolios of a set of largely European global investors using The Economist's portfolio poll. This is a previously unexamined survey data set, which may offer insight into how home bias has changed for European investors with the introduction of the euro.

\section{Summary of our results}

Using cross-section regression analysis of the 1997 US Survey Benchmark data, our findings indicate that transactions costs, as distinct from information asymmetries, help to explain actual portfolio allocations. Using new survey data on firm-level equity holdings from The Economist, we confirm that European firms show home bias in their holdings of European equities. From the start of the EMU convergence period in 1997, the home bias of European firms falls as their holdings of US equities rises. We are unable to find evidence of home bias for the US firms in this sample.

Sections 2 and 3 selectively summarize the research in the two strands of the literature that we are weaving together. Sections 4 and 5 consider the US investor and the European investor, respectively, while section 6 reviews implications of these results for the euro/dollar exchange rate. Section 7 discusses financial market integration in Europe and our plans for future work.

\section{Portfolio Allocations and Transactions Costs}

The extensive literature on "home bias" is the starting point for surveying the relationship between transactions costs and portfolio allocations. If US, European, and global investors more generally already hold the optimal portfolio, then looking for how allocations might change under different transactions cost scenarios holds little interest. The literature suggests that portfolios are not optimal and that the cost in terms of lower return and higher risk is large.

Lewis (1999) uses returns from the S\&P 500 synthetic fund (representing US assets) and Morgan Stanley EAFE (representing the non-US global fund) over the period January 1970 through December 1996 to show that the minimum variance portfolio for the US 
investor allocates about 40 percent of the portfolio to non-US assets, rather than the 10 percent that is actually invested in non-US equity. By not following this minimum variance allocation strategy, the US investor gives up about 50 basis points per year in return (while also decreasing risk), or 80 basis points per year with no change in risk.

Schröder (2002) considers various equity portfolios for European investors, examining risk and return over the period January 1978 to June 2001. The results for some investors are as dramatic as in Lewis' paper, but for other investors, ess so. For a British investor, holding her optimal portfolio of 80 percent non-domestic assets instead of a portfolio of 20 percent non-domestic assets would yield an excess return of 2.2 percent per year. For a German investor, holding his optimal portfolio (which is 100 percent the global allocation) instead of about 20 percent in foreign assets yields an excess return of 3 percent per year. On the other hand, for a French investor, the optimal portfolio is near to her current portfolio allocation of 70 percent domestic French equities, so the gain from additional diversification is small.

The very large gains in terms of return on a portfolio that is diversified internationally suggest that the portfolio allocation strategies of most investors deviate substantially from the optimal allocation. Why is this so in this world of high finance and sophisticated investors? Some researchers have investigated US data on holdings of assets to determine causes of home bias. Along the way, they investigate whether the stylised fact of home bias of US investors is accurate and whether the portfolio stock data are correct. If the underlying holdings data do not represent the portfolio that investors actually hold, then the huge gains to international diversification would be based on 'straw-men' ultimate and initial allocations. (We discuss this further below.)

Transactions costs appear in the literature in a number of places, with differing conclusions. From a theoretical perspective, Lewis (1999) argues that no reasonable transactions costs in financial markets (including information costs as well as the costs of consummating a financial trade) could account for the home bias observed for US investors. On the other hand, the influential work of Obstfeld and Rogoff (2000) explores how costs of engaging in trade in goods is reflected in the investment portfolio, finding that it is not too hard to get reasonable transactions costs in the real world to yield the home bias that is observed in the financial world.

The empirical work follows this theoretical division. Portes and Rey (1999) use the traditional "gravity model" of international trade augmented with information variables such as telephone traffic and number of bank branches to explain bilateral portfolio investment 
flows, with good results. Explaining the flows goes part of the way toward explaining the puzzles about the stock of holdings.

In the empirical work on asset allocation, transactions costs were initially thought to be an unreasonable explanation for US home bias. Tesar and Warner (1995) found that turnover of foreign equities in US portfolios was greater than turnover of domestic equities. Presumably if transactions costs were higher abroad, US investors would not churn this part of their portfolio more frequently. However, Warnock (2001) using benchmark survey data not available to Tesar and Warner, shows that their results owe in part to use of inaccurate data on portfolio holdings.

Ahearne, Griever, and Warnock (2001) suggest that high transactions costs on foreign stock exchanges might increase indirectly the incentive for foreign firms to list on US exchanges, which does help to explain US home bias. Indeed, Pagano, Randl, R*ell, and Zechner (2000) and Pagano, R*ell, Zechner (2001) show that small, fragmented, less liquid, and more costly European exchanges receive fewer cross-listings, and that European firms choosing exchanges on which to list consider the size of transactions costs among other things (including accounting standards and corporate governance rules).

A different strand of the financial research focuses on transactions costs and the rate of return or cost of capital with follow-on implications for portfolio allocations. Domowitz and Steil (2001) and Domowitz, Glen, and Madhaven (2000) using data from Elkins/McSherry LLC (discussed below) calculate that actual trading costs have declined about $2 \frac{1}{2}$ times more in the US than in Europe (1996-1998). Under the assumption of portfolio turnover of twice per year and the US Treasury security as the riskless asset, the authors find that the US investor should put 17 percent into North American assets rather than 27 percent, and 37 percent into French, German, and UK assets instead of 32 percent (see Table 7 in Domowitz, Glen, and Madhavan). They interpret these results as showing a shift in portfolio allocations toward regions with lower transactions costs (and away from the relatively expensive Nasdaq market).

In sum, the recent literature suggests that transactions costs are important, not irrelevant, and go part of the way towards explaining the home bias of the US investor. 


\section{Portfolio Allocations and Exchange Rates}

The relationship between international portfolio allocations and exchange rates has a long and rich theoretical history with an abysmal empirical track record, at least until quite recently. Branson and Henderson (1985) review the portfolio balance theory of exchange rates. Frenkel and Mussa (1985) address the relationship in the context of the current accountexchange rate link. Levich (1985) reports on the general failure to find much of a relationship between portfolio allocations and exchange rates.

Despite the empirical failure in the 1980s, the increasing importance of portfolio flows in international capital markets, the clear relationship between portfolio flows and exchange rates in the context of financial crises in the 1990s (the ERM crisis 10 years ago, subsequent crises in Mexico, Asia, Russia, Brazil, and most recently, Turkey and Argentina), and the apparently puzzling depreciation of the euro since its inception, all have turned researchers back to these portfolio balance models in one form or another.

While few authors depend solely on portfolio stocks or flows to explain exchange rate movements, there is some evidence that portfolio flows themselves are statistically relevant for the determination of exchange rates - or at least the euro/dollar rate - above and beyond other factors such as return or productivity differentials (Tille, Stoffels, and Gorbachev, 2001; Alquist and Chinn, 2002). Sinn and Westermann (2001) find a role for portfolio flows owing to the changing use of the German DM in advance of the euro. Brooks, Edison, Kumar, and Sløk (2001) find that net equity flows are statistically significant even after accounting for rates of return (as measured by interest rates) and stock market valuation changes, although Warnock and Cleaver (2002) find evidence of measurement error in net portfolio flows between the US and Europe. Meredith (2001) focuses on the US productivity shock that affected US stock market capitalization relatively more than European markets, as well as a relatively large increase in issuance of euro-denominated debt, both yielding a dollar appreciation. Fender and Galati (2001) argue that European purchases of US firms are a statistically significant determinant of the euro's depreciation against the dollar.

In sum, notwithstanding the well-known result of Meese and Rogoff (1983), differential rates of return are relevant for explaining exchange rate movements, and so may be cross-border portfolio flows. If transactions costs are important for portfolio allocations and/or rates of return, then they could be important for exchange rate determination as well. 


\section{The US Investor}

That the US investor exhibits home bias is not controversial, the questions are why and how much. In our focus on the US investor, we extend the work of two prior studies to explicitly consider transactions costs.

Ahearne, Griever, and Warnock (2001, henceforth AGW) postulate that cross-listing of foreign equities on US exchanges according to US placement rules is one way to offer the same type of information for a foreign firm as for a US firm, and to offer a transactions cost identical to the purchase or sale of a US stock. Using data from the 1997 benchmark survey of US portfolio holdings in a cross-section regression of about 40 countries, they find that the home bias of the US investor against foreign stocks is reduced the greater is the share of the foreign market that is publicly listed in the US. The increase in demand for foreign equities coming from the information contained in cross-listing increases the share of foreign assets in US investor portfolios from 10 percent to 25 percent. (Alternatively, this amounts to a reduction in the share of US assets in US investor portfolios from 90 percent to 75 percent, a substantial move toward the market-capitalization neutral share of about 50 percent.)

Pinkowitz, Stulz, and Williamson (2001, henceforth PSW) postulate that not all foreign listed shares actually are available for purchase, since, according to La Porta, Lopezde-Silanes, Shleifer, and Vishny (1998), firms located outside the US often are controlled by a large shareholder. Using the 1997 US benchmark survey data in a cross-section regression, PSW find that the share of closely held stocks in a country's markets helps to explain the portfolio allocation of US equity investors and reduces measured home bias. Once closely held stocks are accounted for, the market-capitalization neutral for the US rises from 50 percent (the US share in world market capitalization) to 58 percent.

Taking into account AGW's increased demand for foreign assets and PSW's reduced supply of foreign assets, a good part of the puzzle of US home bias can be explained. ${ }^{1}$ Can transactions costs explain more?

\footnotetext{
${ }^{1}$ Under the assumption of no overlap between closely held shares and cross-listings on US exchanges, it is tempting to add the AGW and PSW results together. This would imply a substantial reduction in the extent of US investors' home bias, from 40 percent to 17 percent. The former is computed as the actual share of US assets in US investor portfolios (90 percent) less the US market neutral share (50 percent). The latter is computed as the share of US assets in US investor portfolios when cross-listings are accounted for (75 percent) less the US market share when closely held shares are removed (58 percent).
} 


\section{Transactions costs}

For transactions costs, we use data supplied by the firm Elkins/McSherry LLC, a firm whose business it is to survey costs of engaging in equity transactions so as to assist other firms in reducing their own transactions costs. The most detailed E/M data track every trade from 1000 investment managers, 1700 global brokers, and 208 exchanges, in 42 countries. We use averages for 41 countries; these cost data break down transactions costs into fees, commissions, and "market impact," where the latter measure attempts to capture the degree to which an individual trade moves the market price. $^{2}$

Most other researchers using the $\mathrm{E} / \mathrm{M}$ data proxy transactions costs with the sum of the 3 components (fees, commissions, and market impact). However, as noted by Domowitz, Glen, and Madhavan (2000), doing so confounds direct costs (fees and commissions) with indirect costs (market impact). Since we are interested in transactions costs arising from a change in the intermediation process from seller to buyer as distinct from the liquidity of the financial exchange on which the transaction takes place, we use the $E / M$ data in disaggregated form.

\section{Empirical method and results}

In order to gauge the importance of transactions costs in US equity portfolio holdings, we estimated cross-section regressions for 1997 using data for 41 countries from the US benchmark survey and from Elkins McSherry. First, we report regressions in which the dependent variable is a measure of bias, similar to AGW (henceforth "bias regressions"). Second, we report regressions in which the dependent variable is the actual share in US equity portfolio holdings, similar to PSW (henceforth "share regressions").

In the bias regressions, the dependent variable is defined as:

BIAS for country $x$

$=1-($ share of country $\mathrm{x}$ in actual portfolios of US investors $)$

$\%($ country x's share of world floating market capitalization),

where floating market capitalization is capitalization less capitalization of closely held shares. This measure of bias was proposed in AGW using actual market capitalization, and redefined in PSW to exclude that portion of market capitalization controlled by large shareholders.

\footnotetext{
2 "Market impact" measures the percentage movement of the buy or sell price from a daily benchmark average of open, close, high, and low prices.
} 
Chart 1 plots the PSW and AGW bias measures for all 41 developed and emerging markets in our dataset, while Chart 2 shows the measures only for developed markets. As discussed above, the PSW bias is smaller than the AGW bias because it corrects for the portion of market capitalization that is closely held. In most cases, the PSW bias reduces the extent to which US investors are underweight a particular country in their portfolios relative to the AGW bias measure. With respect to US assets, however, the PSW bias reduces the extent to which US investors are overweight US assets relative to the market neutral portfolio.

We used BIAS as the dependent variable in cross-section regressions for 41 countries $;^{3}$ results are shown in Table 1 . The explanatory variables included (variable names in parentheses): total transactions costs (TCTOT), the portion of transactions costs representing fees and commissions (TCFC), the portion of transactions costs representing market impact (TCMI), the share of bank assets relative to GDP as a proxy for the importance of bank intermediated finance in a country (BKASSETS), the portion of the foreign market listed on US exchanges (USLISTED), the distance between the country's capital city and New York (DIST), and total trade as a share of GDP (OPEN). Each equation included a dummy variable for the home location (HOME equal to 1 for the US, and 0 otherwise) and a constant term. ${ }^{4}$

To summarize the estimation results, transactions costs - in total or in disaggregated form - are not statistically important in explaining investor bias. The positive, significant coefficient on BKASSETS in equations (3) and (7) suggests that financial diversity of a country has some bearing on the portfolio decisions of US investors over and above what should already be reflected in market capitalization. ${ }^{5}$ A lower degree of financial diversity (a higher share of bank assets in GDP) is associated with higher PSW bias. That is, the more important are banks relative to other sources of finance, the more likely is the US investor to be underweight the equities of that country. The negative, significant coefficient on USLISTED in equations (4) and (7) suggests that underweighting of foreign equities in US portfolios is lower the greater the share of the foreign market that is cross-listed on US

\footnotetext{
3 Although PSW redefine AGW's bias measure to exclude closely held shares, the authors do not use the redefined bias measure in regressions.

${ }^{4}$ We include the HOME dummy rather than drop the US from the sample, as in the AGW and PSW papers. The abridged version of this paper reports estimation results only for equations (3) and (4) on Tables 1 and 2.

${ }^{5}$ Countries that are less financially diverse have a higher share of bank intermediated finance relative to other forms of finance; in these countries, market capitalization should be lower than in more financially diverse economies. Thus, the market neutral share should reflect to some extent the degree of financial diversity of an economy.
} 
exchanges. This finding is similar to the result of Ahearne, Griever, and Warnock (2001), despite a different set of explanatory variables.

In the share regressions, the dependent variable is the actual share of a country's equities in total holdings of US investors. The explanatory variables in the share regressions are identical to those in the bias regressions, except that the country's share in floating market capitalization (FLTSHR) is included as an additional regressor. Results are reported in Table $2 .^{6}$

To summarize the share results, transactions costs are significant and negative, indicating that higher transactions costs are associated with holding a lower actual portfolio share. When transactions costs are disaggregated, the fees and commissions component is statistically more important than the market impact component. A higher fraction of crosslisting in the US market is associated with a statistically significantly higher actual portfolio share, while a greater distance from New York reduces the portfolio share. The estimated coefficients are very small in magnitude. In essence, the HOME dummy explains 83 percent of actual holdings, floating market capitalization another 15 percent, with the remaining 2 percent of holdings attributable to other factors. These results indicate that, although transactions costs are statistically important, researchers have a long way to go in explaining actual portfolio holdings.

\section{The European Investor}

The development of the European capital markets into a pan-European market has been somewhat uneven and, on balance, slower than expected. Policy institutions and researchers have been trying to understand better what stands in the way of developing a pan-European market - what will develop naturally as the market matures, and what role can be played by policy initiatives. The IMF's International Capital Markets (2001) notes that some panEuropean markets have developed (unsecured interbank money market) and others are developing (corporate debt). However, the IMF notes that consolidation of the government securities markets (and we believe similarly the market for private equities) lags in part because of the "fragmented network of 14 national and cross-border securities-settlement-

\footnotetext{
${ }^{6}$ PSW also estimate regressions using actual shares as the dependent variable. In their paper, the objective is to compare coefficients across equations that replace market capitalization shares with floating market capitalization shares. We examine only floating market capitalization shares here, and employ a much different and broader set of explanatory variables.
} 
systems (SSSs) and a patchwork of legal and regulatory requirements" (p. 105). In a recent annual report, the BIS (2000) notes that "one factor ... contribut[ing] to this segmentation of the equity markets ... is the absence to date of an integrated trading infrastructure covering the entire EMU area" (p. 133).

Before looking at the question of settlement costs in Europe, we need to understand the extent to which European investors exhibit home bias, and whether home bias is as large for the European investor as it is for the US investor. We look at this question using data from a quarterly portfolio poll published in The Economist.

\section{The Economist portfolio poll}

In its quarterly survey, The Economist asks international portfolio managers about the consolidated holdings of their firm by instrument (shares of bonds, equities, and cash) and provides a breakdown of equity holdings by area and bond holdings by currency. Each quarterly poll provides information on about 10 firms. Our sample runs from the first quarter of 1992 and ends in the fourth quarter of 2001, and includes 338 equity portfolio allocations by area reported by 10 firms. While The Economist provides information on the totality of a firm's portfolio in terms of equity shares invested in the US, Japan, continental Europe, UK, other Americas, and other Asia, we exclude the latter two areas from our analysis. ${ }^{7}$

For each firm in every time period, we computed a measure of bias for the firm's reported holdings of US, continental European, UK, and Japanese equities. Bias is set equal to one minus the share in the actual portfolio relative to the share in the neutral-weighted portfolio (as measured by Morgan Stanley Capital International (MSCI), also reported in The Economist's survey). If a firm holds the neutral-weighted portfolio, then bias equals zero. If a firm holds a greater share of a particular region's equities than the neutrat-weighted portfolio would suggest, then the portfolio is "overweight" and the bias measure is negative. Conversely, if a firm holds less than the neutratweighted portfolio, bias is positive and the portfolio is "underweight."

Using the location of the firm's headquarters, we assigned home locations to each firm. Table 3 identifies the firms in the sample, their home locations, and the number of quarters for which we have information on their equity holdings by area. Chart 3 plots the

\footnotetext{
${ }^{7}$ There are two caveats on the poll data worth noting. First, The Economist's poll included 13 firms, but we excluded three firms from the sample owing to an insufficient number of observations on each firm. Second, there were two mergers over the period, and we have treated the merged firms as a single firm for the purposes of our analysis.
} 
time series for Merrill Lynch and Lehman Brothers - the US firms in The Economist 's poll with respect to shares of US (top panel) and European (bottom panel) equities. Chart 4 plots the time series for Robeco Group Asset Management, Bank Julius Baer, Commerz International Capital Management, and Credit Suisse Asset Management - four of the six European firms in our dataset - with respect to shares of US (top panel) and European (bottom panel) equities. The solid line in each chart is the MSCI neutral-weighted portfolio allocation. The charts indicate that European firms are overweight European equities (thus evidencing home bias) and underweight US equities, relative to the MSCI neutral-weighted portfolio.

We used simple hypothesis tests to examine whether the mean bias for the four European firms in Chart 4 was statistically significantly different from zero. The results of this exercise are shown in Table 4; in each case, a t-test of the mean bias indicated that the null hypothesis of a zero mean could be rejected at the 5 percent significance level. Each of the four European firms exhibits "home" bias - that is, each firm is overweight European equities relative to the neutral portfolio (with Credit Suisse Asset Management the most overweight). In addition, the four European firms are underweight US assets relative to the neutral portfolio.

Next, we grouped firms by the location of their home, then used simple hypothesis tests to examine whether the mean of the asset holdings of the firms from a particular "home" location evidences home bias - that is, are overweight home assets. In addition, because we have information on the firm's entire portfolio, we are able to examine mean holdings of firms in a given location with respect to "foreign" assets of different countries or regions. We test whether the bias differs significantly from zero, and relatedly, whether bias differs significantly from one home location to another. We look at the entire sample period, as well as two sub-periods: before EMU convergence (1992:Q1-1996:Q4) and EMU convergence (1997:Q1-2001:Q4).

Table 5 shows the mean bias for firms grouped by home location over entire sample from 1992 through 2001. When a t-test of the mean has indicated that the null hypothesis of a zero mean cannot be rejected (at the 5 percent significance level), a " 0 " is shown for the mean bias. Bolded entries on the diagonal give the result for "home" bias.

Does the average holding of European firms exhibit home bias? Yes, European firms are significantly overweight holdings of European equities (-0.3), and underweight holdings of US and Japanese equities relative to the neutralweighted portfolio ( 0.1 and 0.1 , respectively). US firms do not exhibit home bias (in contrast to the literature discussed 
above), are underweight Japan (0.2), and exhibit no bias with respect to European or UK equities. Japanese firms do exhibit home bias (-0.2), are underweight US assets (0.2), and are neutral with respect to European and UK equities.

Table 6 shows the results for the average holding of US firms and European firms for the two sample sub-periods. Has the home bias of European firms changed between the period before convergence and the convergence period? Our results indicate that European home bias has declined, indicating diversification out of European assets. European firms have increased their holdings of US equities, although not enough to move fully to the neutral-weighted portfolio. US firms moved from a neutral position with respect to US and European equities in the early period to acquire a greater share of European equities in the later period.

There are several hypotheses for why the EMU convergence period might have yielded these allocations. Eliminating exchange rate risk no doubt alters the diversification strategy. Perhaps consolidation of financial markets in Europe is leading to a higher covariance among European stocks, thus reducing the value of diversification coming from buying into the various domestic markets. Unfortunately, it is too early to tell whether intraEuropean diversification is increasing (with diversification achieved through a broader array of stocks exhibiting sectoral variation) as found by Adjaouté and Danthine (2001b) or decreasing, with incomplete consolidation of the financial markets within Europe leaving sectoral variation quite small and national correlations quite high (as found by Adjaouté and Danthine 2001a and Fratzscher, 2001).

With respect to transactions costs, Chart 5 shows the decomposition of the E/M data into fees, commissions, and market impact for the European markets and for the US for two dates: 1997 (annual average) and the fourth quarter of 2001. While the charts indicate that fees are relatively unimportant, the extent of the convergence in commissions in the panEuropean market for the latter date is striking. This convergence could reflect financial integration and competition in Europe. And, consistent with the findings from the crosssection analysis, it could be important in explaining the movement into European stocks by US investors in the EMU convergence period. 


\section{Implications for the Euro/Dollar Exchange Rate}

From the cross-section analysis, we determined that transactions costs influence the share of foreign equities held in US portfolios. In particular, we find that the fees and commissions component of the $\mathrm{E} / \mathrm{M}$ data on transactions costs, rather than the market impact component, is statistically significant. Thus, the convergence in commissions in Europe is consistent with the reduction in US investor bias against holdings of European assets in the EMU convergence period that was observed in the portfolio poll analysis. This finding taken in isolation would tend to raise the value of the euro against the dollar.

The portfolio poll data allow inferences on trans-Atlantic capital flows both ways. If European investors diversified out of European assets to a greater extent than US investors diversified into European assets, then the net equity capital flows would tend to favour the dollar. Are holdings data available that would permit us to check this hypothesis? Not yet.

For US outbound trans-Atlantic flows, the US data on portfolio flows (the Treasury International Capital, or TIC data) are suspect because the flow data are classified by transactor, not ultimate beneficiary or obligor. Moreover, as detailed in Warnock and Cleaver (2002), the accumulated and valuation-adjusted flow data yield significantly flawed assessments of the bilateral portfolio holdings for dates between Survey benchmarks. Warnock and Cleaver document that the portfolio flow data underestimate US holdings of euro area equities over a four year period by some 30 percent, even as flows and holdings of US equities by European investors seem to be adequately accounted for. We would expect foreign exchange markets to see through any statistical quirks, even if empirical researchers cannot. Limited data on bilateral equity holdings for most European countries are available from the IMF, and in future work we plan to exploit these data.

To be provocative, we would like to quantify the potential effect of a change in transactions costs on the euro/dollar exchange rate. Suppose a truly pan-European equity market develops, one where intra-European equity markets are linked such that an investor can buy any European asset from any exchange for a single transaction cost. In that scenario, transaction costs across euro area equity markets would equalize, presumably involving some decline from current levels for cross-border transactions and increasing the net rate of return on holdings. This would lead to an increase in US portfolio allocations toward European assets and support an appreciation of the euro. 


\section{Remarks on European Financial Market Consolidation and Future Work}

Financial market consolidation and maturation is a key goal of the EMU process. A substantial effort has been put forward in Europe to better understand the barriers to consolidation and the consequences of it. Many researchers feel that transactions costs matter for European investment. Our results suggest that that concern is correct.

In a recent study for the Centre for European Policy Studies, Lannoo and Levin (2001), use operating profits of financial firms to show that domestic trades on a single national exchange within a country in Europe or on a US exchange within the US incur approximately the same clearing cost. But, since the individual exchanges in Europe are much smaller and offer fewer investment opportunities compared with the US market, a European investor cannot find diversification in his own domestic market. A European investor would therefore want to trade across national exchanges, and in so doing, would bear higher settlement and, more importantly, higher intermediation costs. Euroclear (an international custodian securities depository that services the intra-European market as well as the international market) estimates that 60 percent of the costs of intermediating a crossborder equity trade arise from the maintenance of back-office operations and staff to service multiple markets. An additional 35 percent of the cost of intermediating a cross-border trade arises from the need to have local agents who know the peculiarities of the individual markets.

Lannoo and Levin conclude: “The cost issue is not only a question of domestic versus cross-border, but rather intra versus inter systems. Since no truly integrated European infrastructure exists for securities settlement, moving securities from one system to another will necessarily be more expensive than staying within one system.” (p. i). Thus, what matters for transactions costs intra-Europe is less the cost of the exchange per se and more the cost of the intermediation process. Intra-European trades across exchanges can cost up to 8 times more than domestic trades or trades with the US (Lanoo and Levin, tables 4, 5, and 10). Differences of this magnitude should affect portfolio allocations; we establish econometrically in the cross-section analysis that they do, and make similar inferences using the portfolio poll data.

In future work, we hope to use bilateral equity holdings for European countries to investigate the role played by transactions costs. These results, together with our results for 
US equity holdings, will allow us to estimate the effects of a change in transactions costs on holdings and derive an implication for the euro/dollar exchange rate. 
Dependent variable in all equations is:

BIAS for country $\mathrm{x}=1-[$ ( share of country $\mathrm{x}$ in actual portfolios of US investors) $\div$ (country x's share of world floating market capitalization) ]

\begin{tabular}{|c|c|c|c|c|c|c|c|}
\hline Variable: & (1) & (2) & (3) & (4) & (5) & (6) & (7) \\
\hline TCTOT & $\begin{array}{c}-0.18 \\
(-1.09)\end{array}$ & & & & & & \\
\hline TCFC & & $\begin{array}{c}-0.05 \\
(-0.81)\end{array}$ & $\begin{array}{c}0.00 \\
(0.01) \\
\end{array}$ & $\begin{array}{c}-0.08 \\
(-1.37) \\
\end{array}$ & $\begin{array}{c}-0.08 \\
(-1.02) \\
\end{array}$ & $\begin{array}{c}-0.06 \\
(-0.82)\end{array}$ & $\begin{array}{c}-0.01 \\
(-0.15)\end{array}$ \\
\hline TCMI & & $\begin{array}{c}-0.13 \\
(-0.62) \\
\end{array}$ & $\begin{array}{c}-0.03 \\
(-0.16) \\
\end{array}$ & $\begin{array}{c}-0.14 \\
(-0.66) \\
\end{array}$ & $\begin{array}{c}-0.12 \\
(-0.64) \\
\end{array}$ & $\begin{array}{c}-0.13 \\
(-0.58) \\
\end{array}$ & $\begin{array}{c}-0.05 \\
(-0.28) \\
\end{array}$ \\
\hline BKASSETS & & & $\begin{array}{l}0.16^{* *} \\
(3.25) \\
\end{array}$ & & & & $\begin{array}{l}0.15 * \\
(2.51) \\
\end{array}$ \\
\hline USLISTED & & & & $\begin{array}{c}-0.004 * * \\
(-3.35)\end{array}$ & & & $\begin{array}{r}-0.003 \\
(-1.98)\end{array}$ \\
\hline DIST & & & & & $\begin{array}{c}0.00 \\
(0.85) \\
\end{array}$ & & $\begin{array}{c}0.00 \\
(0.10) \\
\end{array}$ \\
\hline OPEN & & & & & & $\begin{array}{c}0.02 \\
(0.49)\end{array}$ & $\begin{array}{c}-0.05 \\
(-0.99)\end{array}$ \\
\hline HOME & $\begin{array}{l}-1.27 * * \\
(-31.36)\end{array}$ & $\begin{array}{l}-1.28 * * \\
(-22.81)\end{array}$ & $\begin{array}{l}-1.23 * * \\
(-20.20)\end{array}$ & $\begin{array}{c}-1.00 * * \\
(-9.26)\end{array}$ & $\begin{array}{l}-1.22 * * \\
(-20.69)\end{array}$ & $\begin{array}{l}-1.27 * * \\
(-20.97)\end{array}$ & $\begin{array}{l}-1.03 * * \\
(-11.78)\end{array}$ \\
\hline Adjusted R² & 0.54 & 0.54 & 0.60 & 0.62 & 0.55 & 0.54 & 0.66 \\
\hline
\end{tabular}

TCTOT is the total transactions costs reported by Elkins McSherry LLC for 1997. TCFC is the sum of the fees and commissions, while TCMI is the market impact measure. BKASSETS is the ratio of deposit money bank assets to GDP. USLISTED as calculated in Ahearne, Griever, and Warnock (2001). DIST measures the distance between the capital city of country $x$ and New York. OPEN is total trade for country $x$ relative to GDP. HOME is a dummy variable set equal to 1 for the US and 0 otherwise.

T-ratios computed using White standard errors. Significance at the 1 (5) percent level indicated by ** (*).

Constants included but not reported. 
Table 2: Estimation Results for SHARE Regressions

\begin{tabular}{|c|c|c|c|c|c|c|c|}
\hline \multicolumn{8}{|c|}{$\begin{array}{l}\text { Dependent variable in all equations is: } \\
\text { ACTSHR = share of country } \mathrm{x} \text { in actual portfolios of US investors }\end{array}$} \\
\hline Variable: & $(1)$ & $(2)$ & (3) & (4) & $(5)$ & $(6)$ & $(7)$ \\
\hline FLTSHR & $\begin{array}{c}0.15 * * \\
(13.96)\end{array}$ & $\begin{array}{c}0.15 * * \\
(13.64)\end{array}$ & $\begin{array}{l}0.15^{* *} \\
(13.22)\end{array}$ & $\begin{array}{c}0.14 * * \\
(14.12)\end{array}$ & $\begin{array}{c}0.15^{* *} \\
(16.32)\end{array}$ & $\begin{array}{c}0.15^{* *} \\
(13.69)\end{array}$ & $\begin{array}{l}0.14 * * \\
(14.06)\end{array}$ \\
\hline TCTOT & $\begin{array}{c}-0.002 * \\
(-2.15) \\
\end{array}$ & & & & & & \\
\hline TCFC & & $\begin{array}{c}-0.001 * \\
(-2.10) \\
\end{array}$ & $\begin{array}{r}-0.001 * \\
(-2.41) \\
\end{array}$ & $\begin{array}{c}-0.001 * \\
(-2.47) \\
\end{array}$ & $\begin{array}{l}-0.001 \\
(-1.66) \\
\end{array}$ & $\begin{array}{c}-0.001 * \\
(-2.01) \\
\end{array}$ & $\begin{array}{r}-0.001 \\
(-1.62) \\
\end{array}$ \\
\hline TCMI & & $\begin{array}{l}-0.001 \\
(-1.47)\end{array}$ & $\begin{array}{r}-0.001 \\
(-1.66) \\
\end{array}$ & $\begin{array}{l}-0.001 \\
(-1.67) \\
\end{array}$ & $\begin{array}{r}-0.001 \\
(-1.30) \\
\end{array}$ & $\begin{array}{l}-0.001 \\
(-1.46) \\
\end{array}$ & $\begin{array}{r}-0.001 \\
(-1.25) \\
\end{array}$ \\
\hline BKASSETS & & & $\begin{array}{r}-0.000 \\
(-1.00) \\
\end{array}$ & & & & $\begin{array}{l}0.000 \\
(0.14) \\
\end{array}$ \\
\hline USLISTED & & & & $\begin{array}{l}0.000 * \\
(2.40) \\
\end{array}$ & & & $\begin{array}{l}0.000 \\
(1.82) \\
\end{array}$ \\
\hline DIST & & & & & $\begin{array}{c}-0.000 * * \\
(-3.26)\end{array}$ & & $\begin{array}{c}-0.000 * \\
(-2.47)\end{array}$ \\
\hline OPEN & & & & & & $\begin{array}{l}0.000 \\
(0.10) \\
\end{array}$ & $\begin{array}{l}0.000 \\
(1.01) \\
\end{array}$ \\
\hline HOME & $\begin{array}{c}0.83 * * \\
(135.01)\end{array}$ & $\begin{array}{c}0.83 * * \\
(132.39) \\
\end{array}$ & $\begin{array}{c}0.83 * * \\
(125.87) \\
\end{array}$ & $\begin{array}{c}0.83 * * \\
(144.11)\end{array}$ & $\begin{array}{c}0.83 * * \\
(162.39) \\
\end{array}$ & $\begin{array}{c}0.83 * * \\
(132.35) \\
\end{array}$ & $\begin{array}{c}0.83 * * \\
(150.92)\end{array}$ \\
\hline Adjusted $\mathrm{R}^{2}$ & 0.99 & 0.99 & 0.99 & 1.00 & 1.00 & 0.99 & 1.00 \\
\hline
\end{tabular}

FLTSHR equals country i's market capitalization that is not closely held (or floating market capitalization) divided by the sum of floating capitalization for all countries in the sample.

TCTOT is the total transactions costs reported by Elkins McSherry LLC for 1997. TCFC is the sum of the fees and commissions, while TCMI is the market impact measure. BKASSETS is the ratio of deposit money bank assets to GDP. USLISTED as calculated in Ahearne, Griever, and Warnock (2001). DIST measures the distance between the capital city of country $x$ and New York. OPEN is total trade for country x relative to GDP. HOME is a dummy variable set equal to 1 for the US and 0 otherwise.

T-ratios computed using White standard errors. Significance at the 1 (5) percent level indicated by ** (*). Constants included but not reported. 
Table 3: Firms Included in The Economist's Portfolio Poll

\begin{tabular}{|l|c|c|}
\hline Firm & \# Observations & Home \\
\hline Merrill Lynch & 24 & US \\
Lehman Brothers & 36 & US \\
Nikko Securities & 27 & J \\
Daiwa & 36 & J \\
Credit Agricole/Indocam Asset Management & 28 & E \\
Robeco Group Asset Management & 40 & E \\
Bank Julius Baer & 40 & E \\
Phillips \& Drew/ UBS International Investment & 29 & E \\
Commerz International Capital Management & 40 & E \\
Credit Suisse Asset Management & 38 & E \\
\hline
\end{tabular}

US=United States; J=Japan; E=continental Europe

Table 4: Mean Bias of Equity Holdings for 4 European Firms

\begin{tabular}{|l|c|c|}
\hline & \multicolumn{2}{|c|}{$\begin{array}{c}\text { Mean bias for equity holdings of: } \\
\text { Europe }\end{array}$} \\
\hline Robeco Group Asset Management & US & -0.1 \\
Bank Julius Baer & 0.1 & -0.3 \\
Commerz International Capital Management & 0.1 & -0.3 \\
Credit Suisse Asset Management & 0.1 & -0.4 \\
\hline
\end{tabular}


Table 5: Mean Bias of Equity Holdings for Firms Grouped by Home Location

\begin{tabular}{|c|c|c|c|c|}
\hline Firm home & \multicolumn{4}{|c|}{ Mean bias for equity holdings of: } \\
\hline $\begin{array}{l}\text { US } \\
\text { Japan } \\
\text { Europe }\end{array}$ & $\begin{array}{l}\mathbf{0 . 0} \\
0.2 \\
0.1\end{array}$ & $\begin{array}{c}0.2 \\
-\mathbf{0 . 2} \\
0.1\end{array}$ & $\begin{array}{c}0.0 \\
0.0 \\
-\mathbf{0 . 3}\end{array}$ & $\begin{array}{l}0.0 \\
0.0 \\
0.0\end{array}$ \\
\hline
\end{tabular}

Table 6: Mean Bias of Equity Holdings for Selected Time Periods

\begin{tabular}{|c|c|c|c|c|}
\hline \multirow[b]{3}{*}{ Firm home } & \multicolumn{4}{|c|}{ Mean bias for equity holdings of: } \\
\hline & \multicolumn{2}{|c|}{ 92:Q1-96:4 } & \multicolumn{2}{|c|}{$97: Q 1-01: 4$} \\
\hline & US & Europe & US & Europe \\
\hline US & $\mathbf{0 . 0}$ & 0.0 & 0.1 & -0.1 \\
\hline Europe & 0.2 & -0.4 & 0.1 & -0.2 \\
\hline
\end{tabular}


Chart 1: PSW and AGW Bias Measures, All Markets (sorted by PSW)

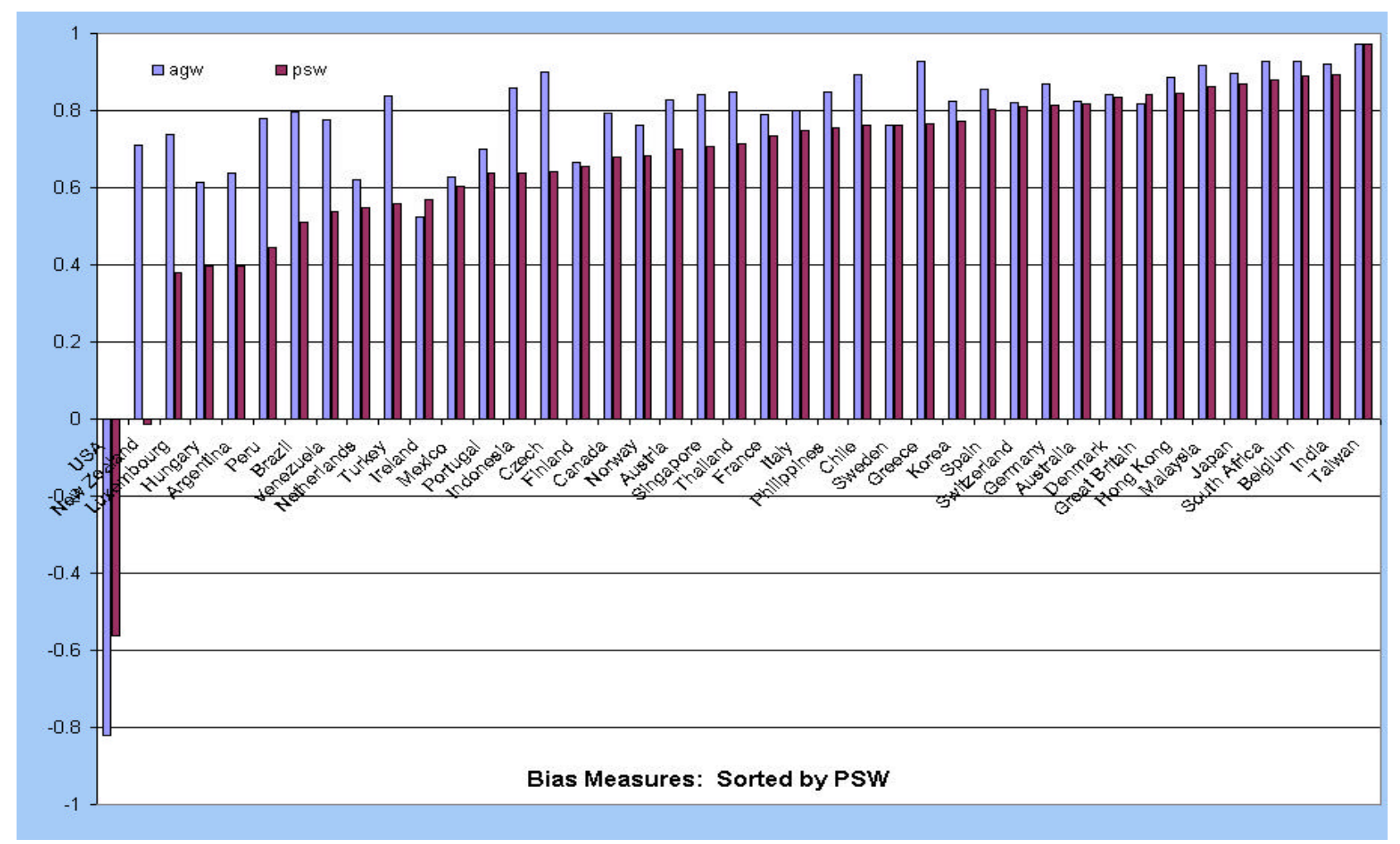

Chart 2: PSW and AGW Bias Measures, Developed Markets (sorted by PSW)

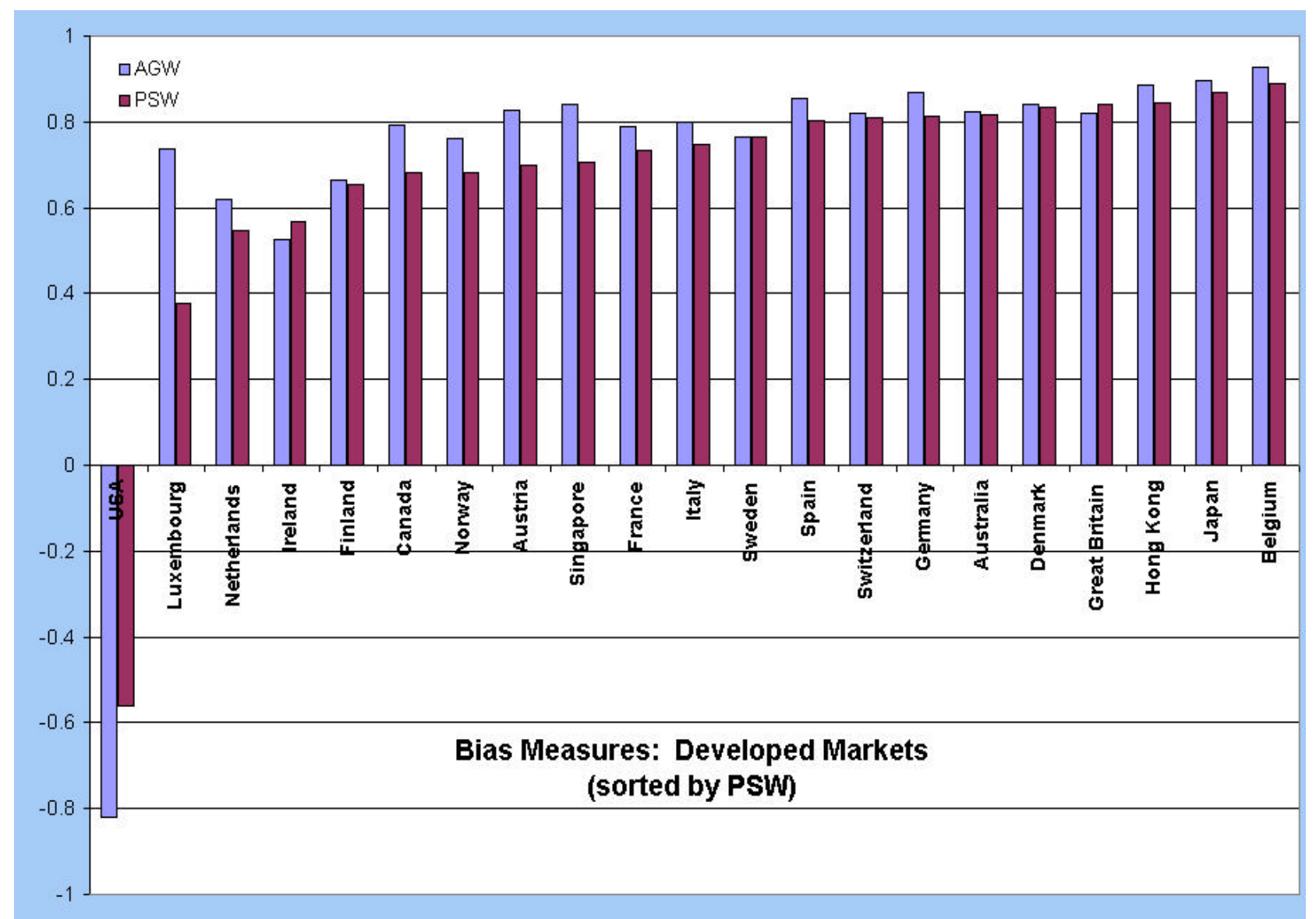


Chart 3: The Economist's Portfolio Poll Data for US firms
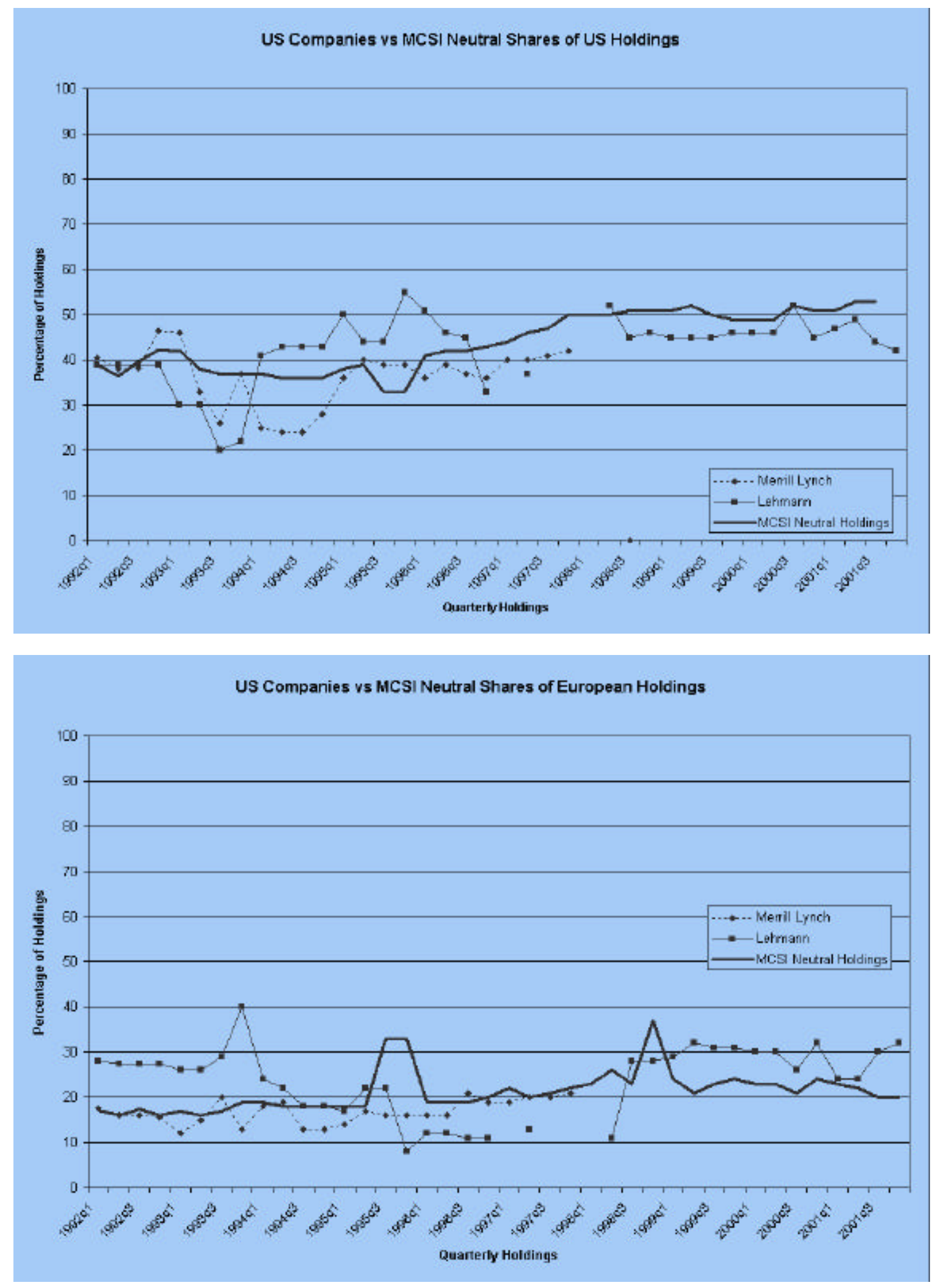
Chart 4: The Economist's Portfolio Poll Data for European firms
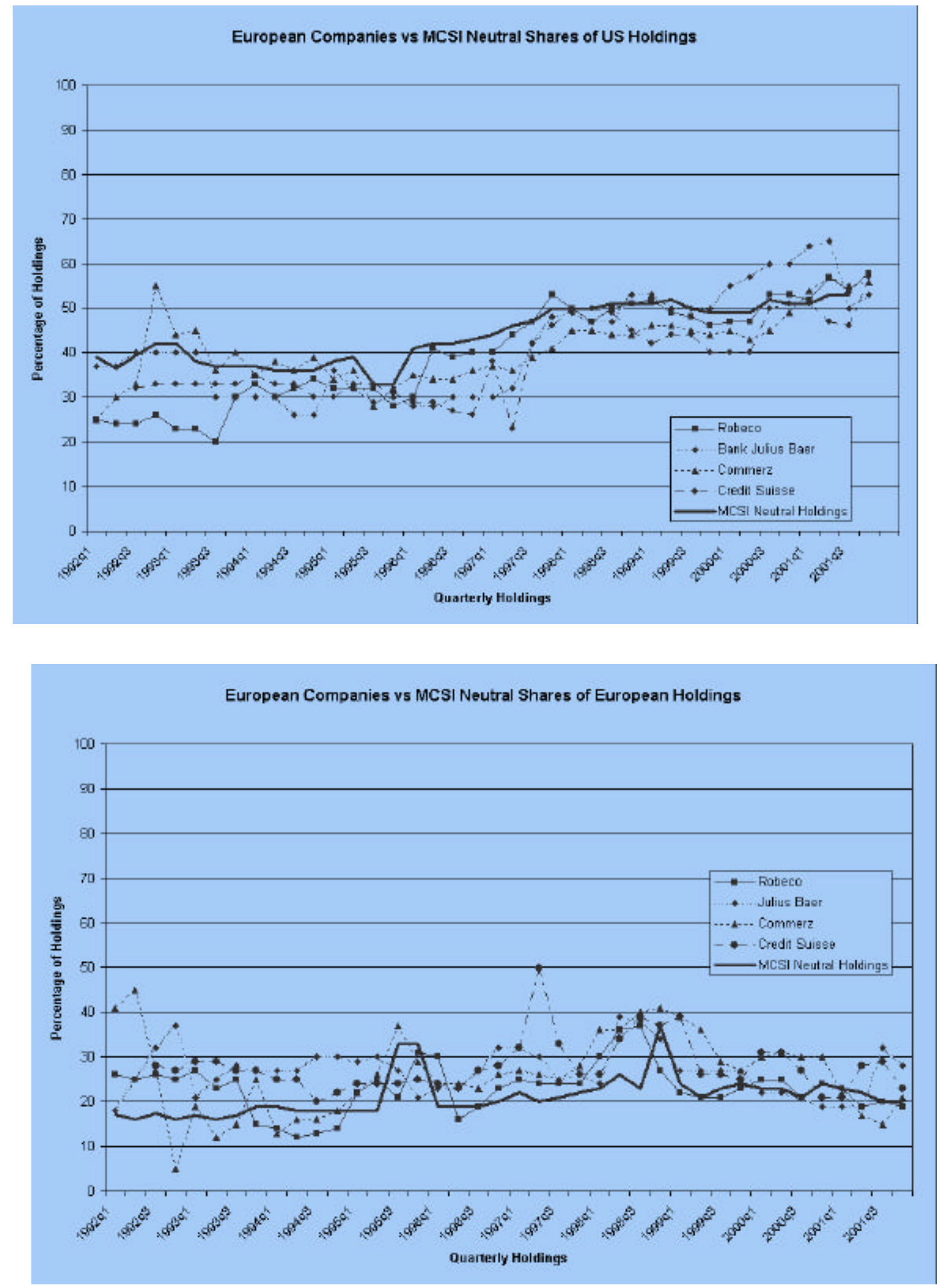
Chart 5: Elkins/McSherry Data on Transactions Costs

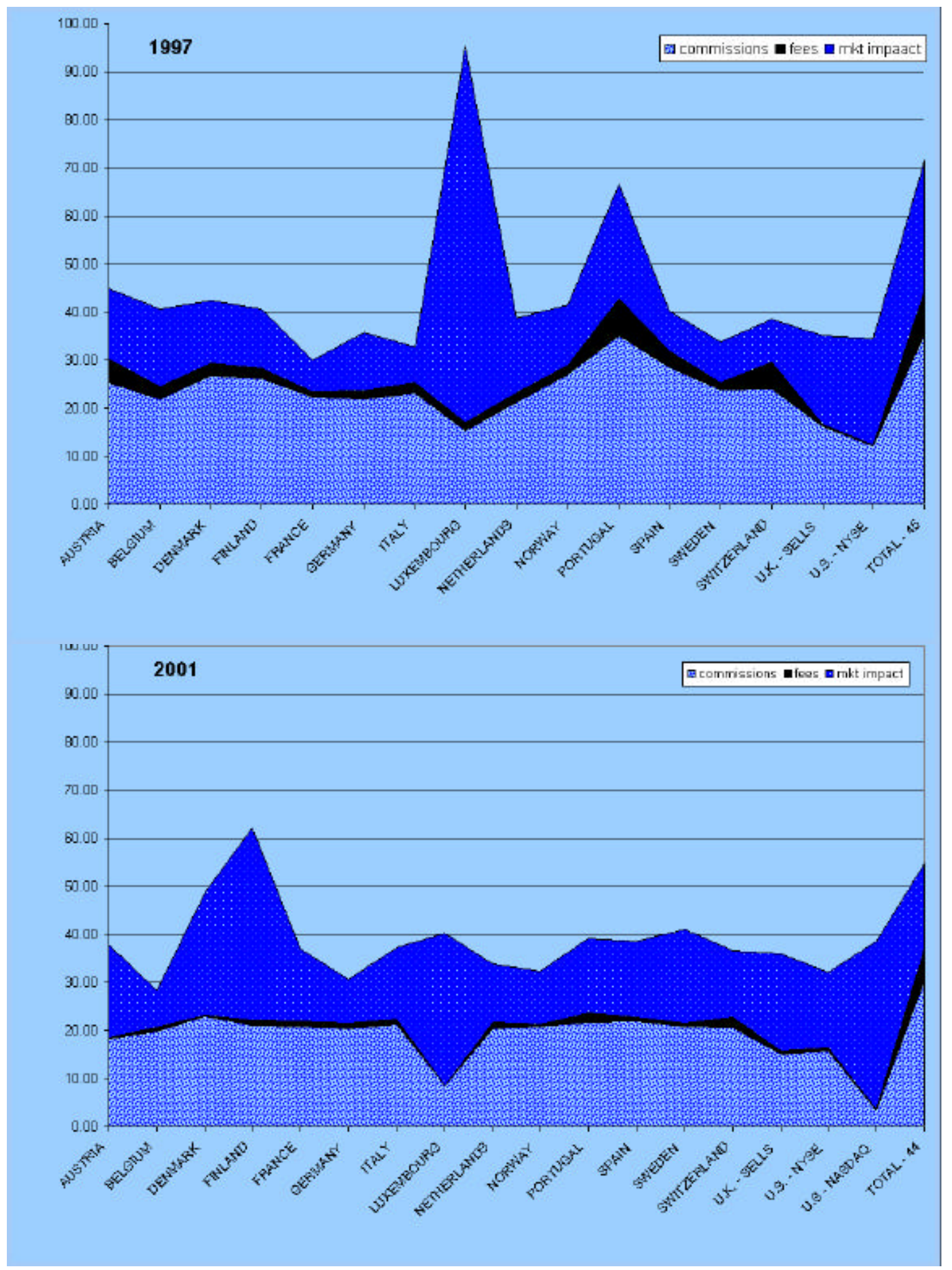




\section{Appendix: Data Sources}

This appendix documents the sources of data for the cross-section regressions reported in section 4 of the paper. The sample includes 1997 data on 41 countries. $^{8}$

US holdings of foreign equities: See "Report on U.S. Holdings of Foreign Long-Term Securities" (2000), http://www.treas.gov/fpis.

Data on US holdings of US securities: See Flow of Funds Accounts of the United States, http://www.federalreserve.gov/releases.

Market capitalization: See Emerging Markets Database 1997 Factbook (1998), International Finance Corporation; World Federation of Exchanges at http://www.worldexchanges.org/index.asp?resolution $\mathrm{X}=1024 \&$ resolution $\mathrm{Y}=768$; Pinkowitz, Stulz, and Williamson (2001).

Floating market capitalization: Computed using market capitalization of firms with closely held shares from Pinkowitz, Stulz, and Williamson (2001).

Transactions costs: Data provided by Elkins/McSherry LLC. See also Emerging Markets Database 1997 Factbook (1998), International Finance Corporation. Following AGW, transactions costs are normalized relative to Korea.

Bank assets: Ratio of deposit money banks assets to total GDP from Financial Structure and Economic Development database. See Beck, Demirgüç, and Levine (1999) and http://www.worldbank.org/research/projects/finstructure/database.htm.

Distance: Mileage between country capital and New York, computed from http://www.indo.com/cgi-bin/dist.

Data on foreign shares listed on US exchanges taken from Ahearne, Griever, and Warnock (2001).

Openness: Share of total exports plus total imports in GDP. See World Development

Indicators (2001), World Bank. For Taiwan and Singapore, see

http://www.state.gov/www/issues/economic.

\footnotetext{
8 Argentina, Australia, Austria, Belgium, Brazil, Canada, Chile, Czech Republic, Denmark, Finland, France, Germany, Great Britain, Greece, Hong Kong, Hungary, India, Indonesia, Ireland, Italy, Japan, Korea, Luxembourg, Malaysia, Mexico, Netherlands, New Zealand, Norway, Peru, Philippines, Portugal, Singapore, South Africa, Sweden, Switzerland, Taiwan, Thailand, Turkey, USA, and Venezuela.
} 


\section{References}

Ahearne, A., Griever, W. and Warnock, F. (2001), 'Information Costs and Home Bias: An Analysis of US Holdings of Foreign Equities', International Finance Discussion Paper No. 691, Board of Governors of the Federal Reserve System.

Annual Report (2000), Bank for International Settlements, Basle.

Adjaouté, K. and Danthine, J. (2001a), 'EMU and Portfolio Diversification Opportunities', Discussion Paper No. 2962, Centre for Economic Policy Research.

Adjaouté, K. and Danthine, J. (2001b), 'Portfolio Diversification: Alive and Well in Euroland!’ Discussion Paper No. 3086, Centre for Economic Policy Research.

Alquist, R. and Chinn, M. (2002), 'Productivity and the Euro-Dollar Exchange Rate Puzzle', Working Paper No. 8824, National Bureau of Economic Research.

Beck, T., Demirgüç, A. and Levine, R. (1999), 'A New Database on Financial Development and Structure', Working Paper, World Bank.

Branson, W. and Henderson, D. (1985), 'The Specification and Influence of Asset Markets', in R. Jones and P. Kenen (eds.), Handbook of International Economics Volume II, Elsevier Science Publishers: Amsterdam.

Brooks, R., Edison, H., Kumar, M. and Sløk, T. (2001), 'Exchange Rates and Capital Flows', Working Paper No. 01/190, International Monetary Fund.

Domowitz, I., Glen, J. and Madhavan, A. (2000), 'Liquidity, Volatility, and Equity Trading Costs Across Countries and Over Time', unpublished Working Paper, Pennsylvania State University.

Domowitz, I. and Steil, B. (2001), 'Innovation in Equity Trading Systems: the Impact on Transactions Costs and Cost of Capital', in R. Nelson, D. Victor, and B. Steil (eds.), Technological Innovation and Economic Performance, Princeton University Press: Princeton.

Fender, I. and Galati, G. (2001), 'The Impact of Transatlantic M\&A Activity on the Dollar/Euro Exchange Rate', BIS Quarterly Review, December, pp. 58-68.

Fratzscher, M. (2001), 'Financial Market Integration in Europe: on the Effects of the EMU on Stock Markets', Working Paper No. 48, European Central Bank.

Frenkel, J. and Mussa, M. (1985), 'Exchange Rates and the Balance of Payments', in R. Jones and P. Kenen (eds.), Handbook of International Economics Volume II, Elsevier Science Publishers: Amsterdam.

International Capital Markets: Developments, Prospects, and Key Policy Issues (2001), International Monetary Fund: Washington, D.C. 
Lannoo, K. and Levin, M. (2001), The Securities Settlement Industry in the EU: Structure, Costs and the Way Forward, Centre for European Policy Studies: Brussels.

La Porta, R., Lopez-de-Silanes, F., Shleifer, A. and Vishny, R. (1998), 'Law and Finance', Journal of Political Economy, vol. 106, pp. 1113-1155.

Levich, R. (1985), 'Empirical Studies of Exchange Rates', in R. Jones and P. Kenen (eds.), Handbook of International Economics Volume II, Elsevier Science Publishers: Amsterdam.

Lewis, K. (1999), 'Trying to Explain Home Bias in Equities and Consumption', Journal of Economic Literature, vol. 37, June, pp. 571-608.

Meese, R. and Rogoff, K. (1983), 'Empirical Exchange Rate Models of the Seventies: Do They Fit Out of Sample?' Journal of International Economics, vol 14, February, pp. 3-24.

Meredith, G. (2001), 'Why Has the Euro Been So Weak?' Working Paper No. 01/155, International Monetary Fund.

Obstfeld, M. and Rogoff, K. (2000), 'The Six Major Puzzles in International Macroeconomics: Is There a Common Cause?' Working Paper No. 7777, National Bureau of Economic Research.

Pagano, M., Randl, O., Röell, A. and Zechner, J. (2000), 'What Makes Stock Exchanges Succeed? Evidence from Cross-Listing Decisions' Working Paper No. 50, Centre for Studies in Economics and Finance, University of Salerno.

Pagano, M., Röell, A. and Zechner, J. (2001), 'The Geography of Equity Listing: Why Do Companies List Abroad?' Working Paper No. 28, Centre for Studies in Economics and Finance, University of Salerno.

Pinkowitz, L., Stulz, R., and Williamson, R. (2001), 'Corporate Governance and The Home Bias', Working Paper No. 8680, National Bureau of Economic Research.

Portes, R. and Rey. H. (1999), 'The Determinants of Cross-Border Equity Flows', Working Paper No. 7336, National Bureau of Economic Research.

'Portfolio Poll', The Economist, selected issues 1992-2001.

'Report on US Holdings of Foreign Long-Term Securities' (2000), Department of the Treasury, April.

Schröder, M. (2002), 'Benefits of Diversification and Integration for International Equity and Bond Portfolios', Centre for European Economic Research.

Sinn, H. and Westermann, F. (2001), 'Why has the Euro been Falling? An Investigation into the Determinants of the Exchange Rates', Working Paper No. 8352, National Bureau of Economic Research. 
Tesar, L. and Werner, I. (1995), 'Home Bias and High Turnover', Journal of International Money and Finance, vol. 14, August, pp. 467-492.

Tille, C., Stoffels, N. and Gorbachev, O. (2001), 'To What Extent Does Productivity Drive the Dollar?' Current Issues in Economics and Finance, vol. 7, August, pp. 1-6.

Warnock, F. (2001), 'Home Bias and High Turnover Reconsidered', Journal of International Money and Finance, forthcoming.

Warnock, F. and Cleaver, C. (2002), 'Financial Centers and the Geography of Capital Flows', International Finance Discussion Papers No. 722, Board of Governors of the Federal Reserve System. 


\section{CENTRE FOR ECONOMIC PERFORMANCE \\ Recent Discussion Papers}

536 M. Manacorda

E. Moretti

535 D. Quah

534 D. Quah

533 R. Dickens

A. Manning

532 S. Machin

A. Manning

531 R. Lydon

A. Chevalier

530 A. Bryson

529 H. Gray

528 E. Mueller
A. Spitz

527

D. Acemoglu

J-S. Pischke

526 J. Schmitt

J. Wadsworth

525 S. Fernie

H. Gray

$524 \quad$ N. Crafts

A. J. Venables

523 E. E. Meade

D. Nathan Sheets

522 D. Quah
Intergenerational Transfers and Household Structure. Why Do Most Italian Youths Live With Their Parents?

One Third of the World's Growth and Inequality

Matching Demand and Supply in a Weightless Economy: Market Driven Creativity With and Without IPRs

Has the National Minimum Wage Reduced UK Wage Inequality?

The Structure of Wages in What Should be a Competitive Labour Market

Estimates of the Effect of Wages on Job Satisfaction

The Union Membership Wage Premium: An Analysis Using Propensity Score Matching

Family Friendly Working: What a Performance! An Analysis of the Relationship Between the Availability of Family Friendly Policies and Establishment Performance

Managerial Ownership and Firm Performance in German Small and Medium-Sized Enterprises

Minimum Wages and On-the-Job Training

Give PC's a Chance: Personal Computer Ownership and the Digital Divide in the United States and Great Britain

It's a Family Affair: the Effect of Union Recognition and Human Resource Management on the Provision of Equal Opportunities in the UK

Globalization in History: a Geographical Perspective

Regional Influences on US Monetary Policy: Some

Implications for Europe

Technology Dissemination and Economic Growth: Some Lessons for the New Economy 
D. Quah

520 C. A. Pissarides

519 D. T. Mortensen

C. A. Pissarides

518 D. Clark

R. Fahr

517 J. Blanden
A. Goodman
P. Gregg
S. Machin

516 A. Chevalier

T. K. Viitanen

515 A. Bryson

R. Gomez

M. Gunderson

N. Meltz

514 A. Manning

513 H. Steedman

512 R. Gomez

M. Gunderson

N. Meltz

511 G. Duranton

D. Puga

510 P.-P. Combes

G. Duranton

509 R. Griffith

S. Redding

J. Van Reenen
Spatial Agglomeration Dynamics

Company Start-Up Costs and Employment

Taxes, Subsidies and Equilibrium Labor Market Outcomes

The Promise of Workplace Training for Non-College

Bound Youth: Theory and Evidence from Germany

Change in Intergenerational Mobility in Britain

The Long-Run Labour Market Consequences of Teenage

Motherhood in Britain

Youth Adult Differences in the Demand for Unionisation:

Are American, British and Canadian Workers That

Different?

Monopsony and the Efficiency of Labor Market

Interventions

Benchmarking Apprenticeship: UK and Continental Europe Compared

From 'Playstations' to 'Workstations': Youth Preferences for Unionisation

From Sectoral to Functional Urban Specialisation

Labor Pooling, Labour Poaching, and Spatial Clustering

Measuring the Cost Effectiveness of an R\&D Tax Credit for the UK

To order a discussion paper, please contact the Publications Unit Tel 02079557673 Fax 02079557595 Email info@cep.lse.ac.uk Web site http://cep.lse.ac.uk 